Original Article (short paper)

\title{
Health in the National Curricular Parameters: establishing relationships with Physical Education
}

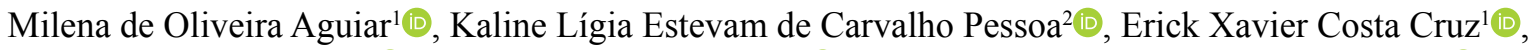 \\ Marcel Alves Franco ${ }^{3}$, Thais Reis Silva de Paulo' ${ }^{1}$, Maria Isabel Brandão de Souza Mendes ${ }^{1}(\mathbb{0}$

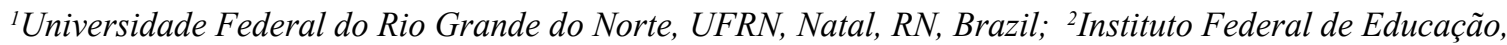 \\ Ciência e Tecnologia do Ceará, IFC, Limoeiro do Norte, Brazil; ${ }^{3}$ Universidade Federal de Pernambuco, \\ UPE, UFPB, Associated Programo f Post-Graduation in Physical Education, Recife, PB, Brazil
}

\begin{abstract}
Aim: The promulgation of the 1996 Education Guidelines and Bases Law promotes debate on the construction of National Curricular Parameters (NCPs) for Basic Education, emerging traditional disciplines and transversal themes. Considering the relevance of NCPs today, the objective of this research was to analyze NCPs related to health and to identify relationships between health and physical education in NCPs for Physical Education in Elementary and High School. Method: This is a documentary study that analyzed the respective documents. Paul Ricœur's hermeneutic approach was used for the interpretation of these documents. Discussion: In this section, it was identified that these documents recognize health as a right; present a dynamic conception of health and emphasize the importance of citizen education. However, the documents contradict each other by emphasizing a reduction of Physical Education to physical exercise, remodeling of habits, emphasized valorization of biological mechanisms, and contradictory facts to understand health dynamics. Conclusion: Finally, the conclusions emphasize the main points in each document, showing that there are advances but there are also divergences between them related to health issues and even setbacks. In addition, new investigations related to this theme are suggested.
\end{abstract}

Keywords: health; physical education; national curricular parameters; documents.

\section{Introduction}

In the mid-1990s, there was a need to make education in Brazil coherent and egalitarian for all regions of the country. The discussion begins with the aim of providing the construction of the National Curricular Parameters (NCPs) which was presented to the public at the end of 1995 by means of a preliminary version for the first and second cycles of elementary education, being "forwarded for consultation and evaluation to teachers and academics from various institutions in the country"1 (p.369).

The NCPs gather documents to contribute to the work of teachers, so as to guide the pedagogical activities in daily life. The reality is that the NPCs have become a timeless document, even when other National Guidelines or the National Curricular Common Base have been modified. Based on a survey conducted in September 2018 of curricular references and other documents such as books available on the State Education Department's websites, we identified that 17 of the 27 Brazilian states are based on NCPs. We are referring to the states of Amazonas, Bahia, Ceará, Federal District, Espírito Santo, Goiás, Maranhão, Mato Grosso, Paraíba, Paraná, Piauí, Rio de Janeiro, Rio Grande do Sul, Rondônia, Roraima, São Paulo, and Sergipe. In Rio Grande do Norte, the Federal Institutes are also based on these documents.

Concomitant to this fact, the relevance of the NCPs are currently due to the recommendation of the same ones in announcements of public tenders to teachers, such as the Child Education Center, a school linked to the Federal University of Rio Grande do Norte, and the public tender of the State of Ceará, both in 2018. As a reference, at the national level we can cite the Teacher Portal of the Ministry of Education, which also continues to provide the NCPs for teachers.

In addition, recent academic productions strengthen the argument about the current state of the document, in view of the marks left and still perpetuated in the scope of the School Physical Education, like the studies of $\mathrm{Makhuol}^{2}$, Guimarães ${ }^{3}$ and Bortoluzzi ${ }^{4}$.

Another contribution of NCPs is the emergence of transversal topics to work on topics that are directed towards forming the student as a citizen because the conventional disciplines are not considered enough to deal with this demand. The crosscutting themes are related to issues of ethics, cultural plurality, the environment, sexual orientation and health ${ }^{5}$.

Faced with such cross-cutting themes, we turn to the issue of health by recognizing that Physical Education has traditionally dealt with this issue. Therefore, the analysis of documents that guide several areas of health knowledge, including for the area of Physical Education, present possibilities to understand health, techniques, and procedures of exercising, the relationship of health with one's own body and the body of others. It is also worth noting the importance 
of NCPs as one of the documents expressing the need to rethink health in the Brazilian school space.

However, although it is necessary to analyze NCPs, it is noted that studies regarding understanding health in NCPs are still scarce, as we identified in a search conducted in September 2017 in the Lilacs and Bireme databases, Capes databases of theses and dissertations, and in Physical Education periodicals (Movement Journal; Physical Education Journal of UEM; Brazilian Journal of Physical Education and Sport; Brazilian Journal of Sport Science; Motivo Journal; Brazilian Journal of Science and Movement; Brazilian Journal of Physical Activity and Health and, Motrivivência Journal). Only two articles were found that investigate NCPs with a focus on health, however, they do not engage in a discussion of understanding health in this document, as they present particularities and do not establish reflections for Physical Education ${ }^{5,6}$.

The study by Marino, Silva, Ferreira ${ }^{5}$ focuses on transversality as a possibility of transformation in education. In addition to analyzing the health NCPs, discussing education for health and health education, the text also presents semistructured interviews and teachers' reports on health education. The study by Bomfin, Anjos, Floriano, Figueiredo, Santos, Silva ${ }^{6}$ presents an approximation between health and the environment. The authors highlight gaps while discussing certain inconsistencies in the objectives of NCPs. In addition, they emphasize that such topics exacerbated the attractiveness of the texts and the character of practicality. Thus, they focus on the issue of education and identify that it is more to conform than to transform reality.

The only study found was a chapter in a book written by Cooper and Sayd ${ }^{7}$ which despite having the conceptions of health in the NCPs as the focus of the transversal topic, when they demonstrate them in analyzes they only briefly mention that the document proposes comprehensive conceptions of health, without providing further elaboration on them.

Faced with the explanation about the studies that are directed to the NCPs of the transversal health topic, we emphasize that a new investigation on this study object becomes relevant and necessary. In order to approach a new view on the NCPs, we chose the following questions to guide our research: What is the understanding of health underlying the National Curricular Parameters which thematize the cross-cutting health topic? What are the implications that this understanding of health can bring to Physical Education? What are the links between health and physical education which are set in the National Curricular Parameters of elementary and high school?

Therefore, the objective of this study is to analyze the NCPs related to the topic of health and identify links between health and physical education in NCPs of primary and secondary education.

\section{Methods}

This is a qualitative study and it is a documentary research that analyzed three documents: the NPCs of health transversal topic and the NCPs of Physical Education for Elementary and high school. The focus of the research was to identify the health topic in these documents. According to $\mathrm{Gil}^{8}$ (p.51), "documentary research is based on materials that have not yet received an analytical treatment, or that can still be reelaborated according to the objects of the research".

For interpreting these documents, we have used the hermeneutic approach of Paul Ricœur9. The interpretation of this author is recognized through the dialectic of explanation and understanding. The hermeneutic approach created possibilities for interpreting the health theme in the analyzed documents, recognizing our focus on Physical Education. According to this author, the comprehension of a text is not reduced to repetition in a similar way. The understanding of a text consists of the creation of new elaborations from what the document presents, as we can identify in his book when he mentions that:

\begin{abstract}
as readers, we can remain in a sort of state of suspension in relation to any kind of reality, or we can imaginatively to upgrade the potential references no overt of text in a new situation, the reader. In the first case, we treat the text as an entity without the world. In the second, we create a new ostensive reference to the type of that the act of reading implies. These two possibilities are equally concerned by the act of reading, conceived as their dialectical interaction ${ }^{9}(p .92)$.
\end{abstract}

Based on the interpretation theory of Paul Ricœur ${ }^{9}$ we learned what was once considered unknown to turn it into something close. The interpretation made it possible to update the meaning of the text.

Regarding the logical construction of the study, it follows the format of subtopics, firstly emphasizing the understanding of health in the transversal document of the theme, and after in the Physical Education documents for each education level, respectively named as relations between health and physical education in elementary education, and relations between health and Physical Education in high school, which are presented in the results and discussion sections.

\section{Results and Discussion}

\section{Health in the NCPS}

In order to seek the understanding of health in the NCPs which approaches health, we believe it is necessary to first identify what are the criticisms in this document, as well as what the paper argues.

The NCPs which approach health are not based on the health-disease process, considering that health is the complete absence of disease ${ }^{10 .}$ Instead, the document criticizes this understanding. The analyzed document also criticizes the understanding of the World Health Organization (WHO) of 
1948, which is still used today in several epistemological and social scenarios, defending that "health is a complete physical, mental, and social well-being and not only the absence of diseases"10 (p. 249).

In this scenario of criticizing the WHO concept of health, we introduce an important study to the debate by Della Fonte and Loureiro ${ }^{11}$, because they mention that this understanding corroborates the fragmentation between the "physical, mental and social" aspects of the human being.

If we observe the NCPs that approach the health topic, it is noticeable that the analyzed document is concerned with bringing this concept into a more critical light. However, Bomfim, Anjos, Floriano, Figueiredo, Santos, Silva ${ }^{6}$ recognizes that there is bias in the way of expressing it due to the fact that health and disease still present a duality of being healthy in the natural sciences. Thus, it demonstrates inconsistency in conceptual construction.

Therefore, it is evident that NCPs do not assume health as the absence of diseases, but as a universal right and a more comprehensive conception throughout the life of people, meaning that "the dynamic conception of health is understood as universal right and as something that people construct throughout their lives, in their social and cultural relations"10 (p. 245). For elaborating the dynamic understanding of health, this document is based on a paper by Georges Canguilhem ${ }^{12}$ entitled "The normal and the pathological", and the article by Dejours ${ }^{13}$ entitled "For a new health conception". We understand that the dynamic conception of health can be conceived as a process in constant movement, and which is not in opposition to the disease, occurring during our living, in our interactions with the environment.

On the health construction throughout people's lives, we highlight the study by Palma ${ }^{14}$. The author understands the need to correlate the life experiences of individuals with each other. Also, highlighting this fact does not make understanding health influenced by genotypic biological determinism obsolete, but amplifies its biases intrinsic to the subjectivity of the subject, and the relationship of individuals to each other and the environment in which they live according to their social context to identify and the construction of individual and collective health. This is what the author called objectivity-without-parentheses, associating hereditary factors with the habits developed in individuality of lifestyle.

In the analyzed document, the health topic comes from a historical understanding of the individual, the socioeconomic and cultural situation of the being and its interrelationship with the environment in which it is inserted ${ }^{10}$. Thus, it is an existential phenomenon inherent to their situation in relation to the context in which it appears.

This understanding of health as an existential phenomenon was approached by a classic author called Hans-Georg Gadamer $^{15}$. This author emphasizes that the concern with one's own health is essential for the human being, although it shows us that we only care about our health when something is not going well. For him, health is a mystery and is not only associated with biological aspects, but also with the life history of the human being and society.
$\operatorname{Gadamer}^{15}$ (p. 109) says that "health is not just a feeling, but being, being-in-the-world, being-with-others, to feel satisfied with the affairs of life and to remain active in them". This existential understanding of health defended by Gadamer ${ }^{15}$ has been defended by researchers in Brazil, such as Nogueira ${ }^{16}$, Mendes ${ }^{17}$ and Ayres ${ }^{18}$. And it is fundamental for Physical Education to look at this phenomenon and to base itself on an expanded understanding of health.

Still commenting on the NCPs of the transversal health topic, we identified that this document presents gaps in the relation of Physical Education as a social practice of health care $^{10}$. It is presented in a contradictory way, according to Della Fonte and Loureiro ${ }^{11}$, as they show that in this way physical education becomes a new consumer market in its essence, giving less priority to the idea of being a fundamental cofactor within the process of maintaining life.

Being considered that immediate acceptability of the sentence "Physical education promotes health", as emphasized by Della Fonte and Loureiro ${ }^{11}$, we emphasize the need to take into account the fact that the construction of Physical Education School and the understanding of health were built during its historical process, whether through eugenics, hygiene, or sports, which generally reinforced the linearity of such conception.

The NCPs of the transversal health topic does not negate the history of health and report its modifications while emphasizing health education in the critical and collective construction of what it is to be, so it suggests modifications in the way to approach it, in addition to criticizing the health understanding of the $\mathrm{WHO}^{10}$. However, it presents gaps, since it presents the idea that a better understanding of biological mechanisms happens in Natural Sciences, and thus suggesting an understanding of health within the health-disease process.

Despite these biases, such a document should be valued because it is one of the documents expressing the need to rethink health in the Brazilian school space, as has been previously mentioned and proposes a dynamic understanding of health.

\section{Relationship between health and Physical Education in Elementary School}

When analyzing the NPCs of the $1^{\text {st }}$ and $2^{\text {nd }}$ cycles of Physical Education, it is a fact that the curricular component and the transversality of health occur as a consequence: "the possibility of experiencing situations of socialization and enjoyment of play activities, without a utilitarian character is essential for health and contribute to the collective wellbeing" $" 19$ (p. 25). In this way, this document highlights important issues and presents a more coherent way of understanding Physical Education and health.

We perceive that the document assumes the subject as a social being and the various characteristics that surround them. While for Physical Education, it can be seen as an ally, helping in the construction of the being-citizen ${ }^{19}$. This document highlights the need for $1^{\text {st }}$ and $2^{\text {nd }}$ cycle students to 
understand corporal practice as responsible for health. At the same time, they should be careful not to influence themselves through the media and to reproduce standards of beauty and health as the only true model ${ }^{19}$.

We see that health appears, in certain aspects, as an objective of Physical Education, as we can identify in the following assertion: "when the individual takes care of health and is integrated into a reference group with which they share socio-cultural activities and whose values do not stimulate drug consumption, they will have more resources to avoid this risk" $^{\prime 19}$ (p. 26). From this, we note that a concern of Physical Education is also to enable changes in habits with the goal of students having more commitment to their own health, being a case of self-care construction.

The NPCs for Physical Education in elementary school try to emphasize other areas of the subject's construction, and with regard to health, highlight the existence of some approaches to Physical Education in Brazil that resulted from the articulation of different psychological theories, sociological and philosophical conceptions ${ }^{19}$. This articulation proved to be a search for understanding what health would be beyond the biological path. It shows a need to understand the individual inserted in the world in which they live, whether related to their habits, or to the social, geographical, or political spheres, among others, with which they participate. Mendes, Araujo, Dias, $\mathrm{Melo}^{20}$ (p. 1592), show that the human body refers to itself being related to the context in which it lives, noting that "disease and health are phenomena considered existential that manifest in the body in certain life situations".

For the $3^{\text {rd }}$ and $4^{\text {th }}$ cycles of elementary education, the NPCs understand that the transversal health topic is automatically linked to the area due to the proximity of its objects of knowledge ${ }^{10}$. In this respect, in the criticisms Macedo ${ }^{21}$, while the transversal topics of NCPs should be of equal importance in all disciplines of the educational curriculum, it structures the subjects related to the disciplines that possess greater similarity, such as Physical Education, which is directly linked to the health theme. The perspective for this document is that it would be up to Physical Education to give specific treatment to the subjects related to the corporal culture of movement in a procedural, conceptual and attitudinal way ${ }^{10}$.

In the context of the body movement culture, corporal practices are contents of the area and allow us to understand health besides a relation of cause and effect. However, what is perceived is a speech that when practicing sports, dance, or gymnastics, there would be a healthy population, automatically attributing the unique responsibility to be healthy to the individuals themselves and their experience of corporal practices, and not to other existing factors which are situated in the midst of the health-disease process.

According to the document, the media emphasizes this conception that health is automatically achieved with corporal practices, in contrast, it addresses the need to analyze and discuss these relationships with School Physical Education ${ }^{10}$. In addition, this linear relationship between the experience of a corporal practice and the acquisition of health was linked to the need to consume products related to these corporal practices (clothes, gyms, supplements) which could show a common idea of healthy people. In the document, it is emphasized that: "In summary, concepts and values about corporal practices are divulged with more emphasis on the products of practice and less on processes" ${ }^{\prime 10}$ (p. 37).

Thus, this document explains that this fosters a possible alienation of the subject from imposed norms and standards, which lives more by buying health-related products than by the actual experience of practice. He also points out that, linked to the work with these media conceptions of health-diseases, the student must be understood as other nuances present in the experience of corporal practices, as well as fear, pain, pleasure, affection, shame, low self-esteem, systematization of exercise programs, risks, injuries, etc. ${ }^{10}$.

Therefore, "it is the responsibility of the School Physical Education to diversify, demystify, contextualize, and above all relativize values and concepts of the corporal movement culture"10 (p. 37). Being that the care related to the subject during the accomplishment of corporal practices must be considered in their experience, their habits of sleep, eating, and social relations, so that a good health program can be formulated that contains corporal practices.

It is around this responsibility that Macedo ${ }^{21}$ affirms that the transversality brings themes of extreme importance for forming the citizen. However, they should not be treated in a transversal way, but in a fundamental way, because the transversality form used in the documents does not advocate that the transversal theme should be completely aligned with the proposal of the disciplines but there is usually a dense emphasis on a certain subject. It is argued that it would be more significant for transversality to assume the main axis and knowledge belonging to the whole formation of the individual, not only linked to a discipline as an especially responsible factor, and when appropriate, addressed by all others.

The transversal health theme in some ways has widened this conception of health directed to the area of Physical Education because due to its historical construction, the biological perspective very much determines the views about this theme ${ }^{10}$. However, it is perceived that the document only turns to a conception of corporal practice that involves the subject in their experience, and when at school Physical Education makes it possible to go beyond the treatment of its contents, discussing health in a multiple and dynamic way. However, it feeds the biomedical model involved in the Physical Education area, by raising the realization of a corporal practice as a way of generating health. Faced with such a statement, we emphasize that this biomedical model "focuses on the human body as the object of interventions, despising it as the subject of existence"20 (p. 1606).

The document of elementary education does not advance much in the totality of Physical Education, although this is not the objective of the health transversal topic. In our analysis, we realized that the document ends up reducing the content to the accomplishment of corporal practices with the health foundation in the biomedical scope, without considering the social and cultural aspects that the practices bring like the requirement for the integrality of being healthy ${ }^{19}$. 
We believe that this conception of health comes from a reduced understanding to the biological aspect, in which the practice of physical activity is situated as a fundamental factor of promotion and prevention, with such a perspective being provided through the discourse of education for health.

\section{Relationship between health and Physical Education in High School}

Physical Education in High School is criticized by the specific document as a curricular component that, in its tradition, is linked to teaching games and sports referring to the rules and norms ${ }^{22}$. Thus, this practice of Physical Education, restricted to the rules and norms of games and sports, fosters an identity that does not match the diversity of existing corporal practices and can promote a lack of interest in Physical Education in students in the school space.

The High School document presents the work of some educators who discuss physical fitness and health like an alternative of work for its classes of Physical Education. For the high school NCPs, students are not encouraged to do corporal practices possibly due to a misunderstanding of what this means, as well as of their poorly discussed relationships with daily life, corroborating the high incidence of obesityrelated diseases and physical inactivity. In this way, the document proposed to return to the aspect of physical fitness and health, and the teacher should think about an attractive program for students ${ }^{22}$.

In relation to some skills and abilities that the students must develop in the High School Physical Education classes, the NCPs indicate the necessity of:

- Understanding the functioning of the human body in order to recognize and modify corporal activities, valuing them as a resource for improving their physical abilities.

- Develop conceptual notions of effort, intensity, and frequency, applying them to corporal practices.

- $\quad$ Reflect on the specific information of the corporal culture, being able to discern and reinterpret them in scientific bases, adopting an autonomous position in the selection of activities and procedures for the maintenance or acquisition of health.

- Assume an active posture in the practice of physical activities and aware of their importance in the life of the citizen ${ }^{22}$ (p. 42).

This document suggests that Physical Education organize groups with similar interests to develop programs ${ }^{22}$. Even with regard to night education, according to LDB, Physical Education becomes optional ${ }^{23}$. To figure this, the document suggests awakening corporal practice through inclusion of programs in the school, which would contribute to improvement in the quality of life of the students; it presents some data on the qualitative effects of corporal practice by the student's night school, contrary to what was thought ${ }^{22}$.

It is also known that Physical Education in its history prioritized the teacher who had knowledge of physiology, anatomy, and first aid, which adopted the position of debater to create dialogues among students and aimed to value their position in the room. This paper insisted on the premise that the teacher should regain his status and that of the discipline as important for acquiring various knowledge, such as physiological benefits for activities with long, medium and short duration $^{22}$. We wondered how this knowledge contributed to forming the citizen, and even more how this contributed to a dynamic understanding of health.

We consider that a proposal designed exclusively for the biomedical model does not meet the health understanding discussed by the NCPs. When delimiting the knowledge to be approached in High School Physical Education from those related to anatomy, physiology, and biology, only the analysis of this document opens a possibility to understand the importance of performing corporal practices ${ }^{22}$. However, the way the document presents this perspective does not make the stimulus of the critical capacity of the subject in face of these contents ${ }^{22}$. This critical capacity can be seen in the study of Darido et al. ${ }^{24}$ (p. 30) when it defends Physical Education that integrates the citizen in the contents of the corporal culture.

We believe that school is the perfect opportunity for some discussions: weight control and development of good health habits in the student, for example, that allow the continuity of the corporal practices when they understand the necessity of these for their life beyond the school context.

We defend the importance of Physical Education for health and education; however, it is not realistic to make the teacher of this curricular component responsible for performing corporal practices beyond the school context. Together with the NCPs, we seek to break the duality of health and disease and understanding them as antonyms, but we also seek to improve the gaps found. We are sensitive to the claim of the health concept adopted by the NCPs, although it sometimes presents an inconsistency since there were certain confusions during the course of the document, which in a stealthy way flowed from its own understanding of health which was initially defended.

\section{Conclusions}

From the analysis of NCPs related to the health transversal topic and NCPs in Physical Education in elementary and high school, we understand that there are advances, but also that there are divergences between these documents related to health issues and even regressions.

With regard to the advances, we highlight the dynamic conception of explicit health in the NCPs of the health transversal topic and the recognition that health is a right of all citizens. In contrast to these highlights, what still stands out in the PCNs of physical education in elementary and high school related to health is the biomedical model. Although we highlight that some biases that contribute to reducing what would be Physical Education, what is demonstrated in our interpretation is a contradiction with respect to what the 
document itself preaches. We also highlight notes for each level of education in health.

For elementary school, Physical Education in the first and second cycles is not even compulsorily addressed by the licensed document, and although the importance for the construction of the citizen is presented, we still identify Physical Education as a way to transform habits without a proper reflection or without an approximation to daily life. In turn, in the last cycles there was an emphasis on the discussion of Physical Education reinforcing the biomedical model, however reduced to performing corporal practice, being even more emphasized in high school. In this last level, the NCPs consider that the teacher must take back the knowledge of the biological area to regain their value to the school (students, other teachers, board). However, it is necessary to reflect on a perspective that does not prioritize one area or another, rather than dialogue. Thus, many other contents can be approached, giving consideration to the social, contextual and geographical characteristics, among others already mentioned in the transversal themes document, being an excellent opportunity to dialogue with other curricular components, such as Geography, for example.

We understand the real need for education that raises the aspects of corporal practices as an element that can bring health benefits, to the extent that the student, or any other subject, becomes aware of this situation. However, the proposal of a Physical Education that resumes the aspect of physical fitness and health in a biomedical perspective within the classroom, without mentioning the other aspects of school Physical Education such as culture, values, social relations, among others, only reduces the discipline to a hygienist slope, which is portrayed in the historical part by the NCPs themselves.

As a way to highlight the contributions that NCPs bring to the health theme, we recognize that this document was and still is a parameter for teachers in their daily actions. We also identified that certain points may advance. As a way of continuing an investigation on the subject of health in the scope of Physical Education in later studies, the gaps found in NCPs serve as starting points for an analysis of the document that will replace it in schools, which is the National Base Common Curricular (NBCC).

\section{References}

1. Bonamino A, Martínez SA. Diretrizes e Parâmetros Curriculares Nacionais para o Ensino Fundamental: a participação das instâncias políticas do Estado. Educ. Soc. 2002; 23(80): 368-85.

2. Makhoul CS. Análise da produção bibliográfica em periódicos brasileiros sobre o corpo na área da educação física. Londrina. Tese [Doutorado em Ensino de Ciências e Educação Matemática] Universidade Estadual de Londrina; 2017.

3. Guimarães CCPA. Desafios da escola pública e a esperança por uma escola saudável: a educação física tecendo saberes. São Paulo. Tese [Doutorado em Educação Física] Universidade São Judas Tadeu.; 2017.
4. Bortoluzzi MB. A educação física escolar na perspectiva do professor: descrevendo e interpretando teorias subjetivas. Campinas. Tese [Doutorado em Educação Física] Universidade Estadual de Campinas; 2018.

5. Marinho JCB, Silva JA, Ferreira M. A educação em saúde como proposta transversal: analisando os Parâmetros Curriculares Nacionais e algumas concepções docentes. Hist. cienc. saude-Manguinhos 2015; 22(2):429-44.

6. Bomfim AM, Anjos MB, Floriano MD, Figueiredo CSM, Santos DA, Silva CLC. Parâmetros Curriculares Nacionais: uma revisita aos temas transversais meio ambiente e saúde. Trab. Educ. Saúde 2013; 11(1): 27-52.

7. Cooper CLF, Sayd JD. Concepções de saúde nos Parâmetros Curriculares Nacionais. In: A saúde em debate na Educação Física - volume 2. Blumenau, Nova Letra; 2006. p. 179-200.

8. Gil AC. Métodos e técnicas de pesquisa social. 6 ed. São Paulo: Atlas; 2016.

9. Ricœur P. Teoria da interpretação: o discurso e o excesso de significação. Tradução Artur Mourão. Lisboa, Edições 70, 1999.

10. Brasil. Secretaria de Educação Fundamental. Parâmetros curriculares nacionais: terceiro e quarto ciclos do ensino fundamental (Tema Transversal Saúde). Secretaria de Educação Fundamental - Brasília: MEC/SEF; 1998.

11. Della Fonte SS, Loureiro R. A ideologia da saúde e a Educação Física. Rev. Bras. Cienc. Esporte. 1997; 18(2): 126-132.

12. Canguilhem G. O normal e o patológico. Coleção Campo Teórico. 4. ed. Rio de Janeiro, Forense Universitária, 1995.

13. Dejours C. Por um novo conceito de saúde. Rev. bras. saúde ocup. 1986; 14(54): 7-11.

14. Palma A. Educação Física, corpo e saúde: uma reflexão sobre outros "modos de olhar". Rev. Bras. Cienc. Esporte. 2001; 22(2): 23-39.

15. Gadamer HG. O mistério da saúde: o cuidado da saúde e a arte da Medicina. Portugal, Edições 70, 1993.

16. Nogueira RP. Para uma análise existencial da saúde. InterfaceComunic., Saúde, Educ. 2006; 10(20):333-345.

17. Mendes MIBS. Mens Sana in Corpore Sano: saberes e práticas educativas sobre corpo e saúde. Porto Alegre, Sulina, 2007.

18. Ayres JRCM. Uma concepção hermenêutica de saúde. Physis: Rev. Saúde Coletiva. 2007; 17(1): 43-62.

19. Brasil. Secretaria de Educação Fundamental. Parâmetros curriculares nacionais: Educação física /Secretaria de Educação Fundamental. - Brasília: MEC/SEF; 1997.

20. Mendes MIBS, Araujo AC, Dias MA, Melo JP. Reflexões sobre corpo, saúde e doença em Merleau-Ponty: implicações para práticas inclusivas. Movimento. 2014; 20(4): 1587-1609.

21. Macedo EF. Parâmetros Curriculares Nacionais: a falácia de seus temas transversais. In: Moreira AFB, organizador. Currículo: políticas e práticas. Campinas, Papirus, 2000. p. 43-58.

22. Brasil. Secretaria de Educação Média e Tecnológica. Parâmetros Curriculares Nacionais (Ensino Médio) Linguagens, Códigos e suas Tecnologias. Brasília, 2000.

23. Brasil. [Internet] Lei de Diretrizes e Bases da Educação Nacional. Lei n. 9.9394, de 20 de dezembro de 1996. Brasília: Presidência da República; 1996. Available from: http://www.planalto.gov. br/Ccivil_03/leis/L9394.htm [Accessed 15th jan 2018]. 
24. Darido SC, Rangel-Betti IC, Ramos GNS, Galvão Z, Ferreira LA, Mota e Silva EV et al. A Educação Física, a formação do cidadão e os Parâmetros Curriculares Nacionais. Rev. paul. Educ. Fís. 2001; 15(1):17-32.

\section{Corresponding author}

Maria Isabel Brandão de Souza Mendes

Rua Américo Soares Wanderley, 1856, Bl. C, apto. 1003, Capim Macio, 59082-060, Natal, RN.

Email: isabelbsm1@gmail.com

Manuscript received on November 22, 2018

Manuscript accepted on February 14, 2019

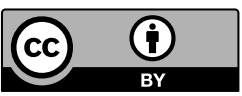

Motriz. The Journal of Physical Education. UNESP. Rio Claro, SP, Brazil - eISSN: 1980-6574 - under a license Creative Commons - Version 4.0 